\title{
Teacher Training's Needs in University Context: A Case Study of a Chilean University of Applied Sciences
}

\author{
https://doi.org/10.3991/ijet.v16i09.21389 \\ Diego Gormaz-Lobos $\left.{ }^{(}\right)$, Claudia Galarce-Miranda \\ Universidad de Talca, Curicó, Chile \\ diego.gormaz@utalca.cl \\ Hanno Hortsch \\ Technische Universität Dresden, Dresden, Germany \\ Carolina Vargas-Almonacid \\ INACAP, Talca, Chile
}

\begin{abstract}
Frequently, the teacher training programs in Chilean universities are designed from a generic vision of pedagogical competencies (not necessarily specialized for a particular discipline) and in form of face-to-face activities. The new demands of the society and the economy, the constant specializations of the scientific fields, and the incorporation of new technologies for teaching and learning make that the typical contemporary forms for the teacher academic training must be reviewed and analyzed. The main goal of this paper is to present the results of a survey about teaching needs on Engineering Pedagogy in engineering departments of INACAP (a Chilean university of applied sciences). In general, the instrument and indicators seek to obtain information about: (i) needs/demands related to engineering didactic fundamentals, (ii) requirements for the structuring and assessment of teaching-learning processes in a university context, (iii) requirements for the design and evaluation of face-to-face as well as online teaching-learning activities in engineering, among others. The project was led by the International Center of Engineering Education (CIEI) at the University of Talca (Chile) in cooperation with the academic staff of INACAP at the Talca campus, under the pedagogical support of the Technische Universität Dresden (Germany), Faculty of Education. Based on these research results and on the IGIP Curricula, a teacher training program for the academic staff of the engineering schools in online modality was designed and implemented.
\end{abstract}

Keywords - Teaching Training Needs in Engineering, Online University Teacher Training, Engineering Pedagogy 


\section{Introduction}

\subsection{Context of the university teacher training in Chilean universities}

There are no doubts about the high importance of the skills of the academic staff: the pedagogical competencies of the academic staff are undoubtedly a key factor in the success of the professional training of students of all types of universities and vocational schools $[1,2,3]$. The international scientific literature in Spanish-speaking countries regarding the university teacher's training shows a clear inclination towards training courses designed from a generic vision of university teaching and not necessarily specialized in a particular discipline. In most cases, the training programs and courses for the university academic staff try to strengthen the pedagogical competencies regarding the design and evaluation of teaching-learning processes, the implementation of various active methodological strategies and the generation of "new" teaching resources, among others [2, 3, 4, 5]. In the case of Spain, in 2019 was characterized the situation of teacher training programs at universities, noting that most of the programs consist of "general" courses, which are principally aimed at promoting the generic pedagogical competences, as well as the general analysis and reflection of the teaching task itself [6]. The author elaborates on this idea in the conclusions of her research, where she emphasizes that the majority of university teachers receive "training that is little linked to their practice and disconnected from their classroom experiences" [6]. In the Chilean university context, there is not yet a complete scientific analysis of all the training programs for the academic staff at different types of universities. Currently exists public information disseminated by institutions that accounts for pedagogical training programs oriented to all disciplines. Table 1 exposes the examples of three main Chilean universities with a typical teacher-training program in the contemporary Chilean university context: the Pontificia Universidad Católica de Chile (Pontifical Catholic University of Chile, PUC) [7], the Universidad de Chile (University of Chile, UCH) [8] and Universidad de Talca (University of Talca, UTALCA) [9].

Table 1. Overview of teacher training programs at Chilean universities [7, 8, 9].

\begin{tabular}{|l|l|l|}
\hline \multicolumn{1}{|c|}{ Program } & \multicolumn{1}{|c|}{ Module } & \multicolumn{1}{c|}{ Goal } \\
\hline \multirow{2}{*}{$\begin{array}{l}\text { Teaching in } \\
\text { Higher Educa- } \\
\text { tion } \\
\text { (PUC) }\end{array}$} & 1. Designing Courses & $\begin{array}{l}\text { To formulate course learning objectives focused on student } \\
\text { learning, and to select methodologies and coherent evaluation } \\
\text { strategies to evaluate the learning achievement. }\end{array}$ \\
\cline { 2 - 3 } & Outcomes & $\begin{array}{l}\text { To recognize the main elements and characteristics of assessment } \\
\text { in real evaluative situations, and to select and design instruments } \\
\text { and assessment guidelines relevant to an evaluation situation. }\end{array}$ \\
\cline { 2 - 4 } & $\begin{array}{l}\text { 3. Planning for Active } \\
\text { Learning }\end{array}$ & $\begin{array}{l}\text { To identify the main elements for the design active learning } \\
\text { activities, and to design a unit of a course using an active learning } \\
\text { methodology. }\end{array}$ \\
\hline \multirow{2}{*}{$\begin{array}{l}\text { Innovation } \\
\text { and University } \\
\text { Teaching } \\
\text { (UCH) }\end{array}$} & $\begin{array}{l}\text { 1. Higher education: } \\
\text { contexts and challenges. }\end{array}$ & $\begin{array}{l}\text { To analyse the current and future characteristics and challenges of } \\
\text { higher education in Chile, Latin America and the world. }\end{array}$ \\
\cline { 2 - 3 } $\begin{array}{l}\text { 2. SoLT (Scholarship of } \\
\text { Learning and Teaching). }\end{array}$ & $\begin{array}{l}\text { To identify the implications of the SoLT model in the develop- } \\
\text { ment, research and innovation in higher education. }\end{array}$ \\
\cline { 2 - 3 } $\begin{array}{l}\text { 3. Teaching for high } \\
\text { To establish the implications and scope of high quality and effec- }\end{array}$ \\
\hline
\end{tabular}




\begin{tabular}{|c|c|c|}
\hline & $\begin{array}{l}\text { quality teaching-learning } \\
\text { in higher education. }\end{array}$ & $\begin{array}{l}\text { tive teaching and learning, based on empirical evidence, in the } \\
\text { context of higher education and the challenges of the society. }\end{array}$ \\
\hline & $\begin{array}{l}\text { 4. Innovation, active } \\
\text { learning and ICT's. }\end{array}$ & $\begin{array}{l}\text { To implement active methodologies within the classroom, con- } \\
\text { sidering current teaching trends, especially from the disciplines } \\
\text { themselves. }\end{array}$ \\
\hline & $\begin{array}{l}\text { 5. Learning committed to } \\
\text { the environment and the } \\
\text { community. }\end{array}$ & $\begin{array}{l}\text { To design teaching processes linked to the community and the } \\
\text { environment, that are related to the disciplinary learning and the } \\
\text { corresponding graduation profile. }\end{array}$ \\
\hline & $\begin{array}{l}\text { 6. Classroom manage- } \\
\text { ment in contexts of } \\
\text { diversity. }\end{array}$ & $\begin{array}{l}\text { To implement actions, within the classroom, that consider hetero- } \\
\text { geneity and inclusion, capable of committing to the learning of } \\
\text { each and every student. }\end{array}$ \\
\hline & $\begin{array}{l}\text { 7. Education with a focus } \\
\text { on gender and sexual } \\
\text { diversity. }\end{array}$ & $\begin{array}{l}\text { To generate a holistically and comprehensively understand of the } \\
\text { teaching and learning processes, from the perspective of gender } \\
\text { and diversity (LGTBIQ) }\end{array}$ \\
\hline & $\begin{array}{l}\text { 8. Evaluation of learning } \\
\text { outcomes in higher } \\
\text { education. }\end{array}$ & $\begin{array}{l}\text { To produce assessment instruments and situations, according to } \\
\text { collect evidence of student learning outcomes in higher educa- } \\
\text { tion. }\end{array}$ \\
\hline \multirow{4}{*}{\begin{tabular}{|l|} 
\\
Pedagogical \\
training pro- \\
gram based on \\
the competen- \\
cy model \\
(UTALCA)
\end{tabular}} & $\begin{array}{l}\text { 1. Determination of new } \\
\text { demands and needs for } \\
\text { professional training. }\end{array}$ & $\begin{array}{l}\text { To strengthen the capacities to establish relationships between } \\
\text { social and technological changes and the exercise of the academic } \\
\text { professions and professional teaching practices. }\end{array}$ \\
\hline & $\begin{array}{l}\text { 2. Achieving significant } \\
\text { learning. }\end{array}$ & $\begin{array}{l}\text { To strengthen the ability to design significant learning situations } \\
\text { according to the logic of competency-based education. }\end{array}$ \\
\hline & $\begin{array}{l}\text { 3. Assessment, evalua- } \\
\text { tion and decision mak- } \\
\text { ing. }\end{array}$ & $\begin{array}{l}\text { To strengthen the ability to assess the progress and learning of the } \\
\text { students, in a coherent and valid way to the competency-based } \\
\text { teaching framework. }\end{array}$ \\
\hline & 4. Designing a syllabus. & $\begin{array}{l}\text { To design a competency-based module program (syllabus) ac- } \\
\text { cording to the requirements of each study plan based on the } \\
\text { institutional format. }\end{array}$ \\
\hline
\end{tabular}

In general, the training courses are characterized by an educational sciences perspective, supplemented by contents related to the demands of Chilean society in the 21 st century. All training programs are based on the constructivist theory of the active learning process but specifically, UTALCA presents the conception of "competencybased" training. Relevant in the program of UCH is the focus on diversity and gender: topics that have strongly marked the Chilean university context in the last 5 years. However, the question remains about the degree of effectiveness of this kind of course for the teacher training and its real "closeness" with the disciplinary reality of the different modules at students training programs (engineering sciences for instance).

\subsection{The case of INACAP}

INACAP is a Chilean university of applied sciences and vocational school (postsecondary education) with more than 27 campuses in different regions of Chile, that offer programs in different engineering fields. The current national and international scenarios, related to the new regulatory framework for higher education in Chile (Law No. 21.091 / 2018) and Industry 4.0, have motivated INACAP's Higher Education System (university and vocational school) to develop a teacher's training program, that meets learning needs of future technicians and professionals. INACAP has an institutional training plan for teachers and its academic staff with the purpose to update their technical and pedagogical competencies. Further, it pursues to promote 
pedagogical innovations that have a significant impact on the learning process of students.

The teachers training is based on three principles: (1) to create connections between teachers and the industry, in order to build learning scenarios for their students, (2) to provide teachers with experiences in the industry, to empower them with technical skills and thereby promote innovation projects from the classroom to the industry, and (3) to assume and apply teaching technologies. The courses of the training plan are organized in two learning progression levels: advanced and expert. The first is focused on the development of a diploma in teaching in higher education and a plan to improve basic teaching skills. The second is focused on post-degree development and specialization within academic areas. The training proposal is completely centrally defined and it is delivered mainly online for the purpose to achieve coverage in all the 27 campuses throughout the Chilean territory.

Table 2. Overview of INACAP Training's plan for teachers and academic staff.

\begin{tabular}{|c|c|c|}
\hline Program & Course & Objective \\
\hline \multirow{7}{*}{$\begin{array}{l}\text { Diploma Teach- } \\
\text { ing in Higher } \\
\text { Education }\end{array}$} & $\begin{array}{l}\text { Teaching in Context of } \\
\text { Higher Education in } 21 \text { 'st } \\
\text { Century }\end{array}$ & $\begin{array}{l}\text { Ponder on required teaching competencies to face the para- } \\
\text { digm change caused by competence training. }\end{array}$ \\
\hline & Neuroeducation & $\begin{array}{l}\text { Set up a dialogue between neuroscience and its contribution } \\
\text { to education, in order to improve proposals and learning } \\
\text { experiences. }\end{array}$ \\
\hline & Innovation & $\begin{array}{l}\text { To bring the teacher closer to an innovation process that } \\
\text { mainly describes networking through INACAP ecosystem to } \\
\text { promote innovation and entrepreneurship. }\end{array}$ \\
\hline & General Didactics & $\begin{array}{l}\text { To bring teachers closer to new teaching-learning processes } \\
\text { and procedures linked to the competency-based approach } \\
\text { and use of technologies. }\end{array}$ \\
\hline & Learning Evaluation & $\begin{array}{l}\text { To provide assessment tools necessary to improve student } \\
\text { learning with a competency-based approach. }\end{array}$ \\
\hline & $\begin{array}{l}\text { Teaching Learning Plan- } \\
\text { ning }\end{array}$ & $\begin{array}{l}\text { To provide teachers with the curricular knowledge needed to } \\
\text { improve their students learning within a competency-based } \\
\text { approach. }\end{array}$ \\
\hline & B- and E-learning teaching & $\begin{array}{l}\text { To provide theoretical elements necessary for blended and } \\
\text { online teaching. }\end{array}$ \\
\hline \multirow{2}{*}{$\begin{array}{l}\text { Post degree } \\
\text { Teaching in } \\
\text { Upper Technical } \\
\text { Education }\end{array}$} & $\begin{array}{l}\text { Innovation } \\
\text { Upper Technical Teaching } \\
\text { Digital courses/module } \\
\text { General Didactics } \\
\text { Learning Evaluation } \\
\end{array}$ & $\begin{array}{l}\text { To promote innovation and inter-disciplinary work, adapting } \\
\text { to the new regulatory scenarios of higher education for upper } \\
\text { technical training. } \\
\text { Higher level of contents and methods for each course. }\end{array}$ \\
\hline & $\begin{array}{l}\text { Certification Alternative } \\
\text { Credentials Miriadax } \\
\text { Teaching in Upper Tech- } \\
\text { nical Training. }\end{array}$ & \\
\hline \multirow{2}{*}{$\begin{array}{l}\text { Upper Technical } \\
\text { Specialization } \\
\text { courses }\end{array}$} & $\begin{array}{l}\text { Introduction to math prob- } \\
\text { lem solving activation } \\
\text { (ARPA) }\end{array}$ & $\begin{array}{l}\text { To provide tools and support to implementation of problem- } \\
\text { solving activities in the classroom, gradually and systemati- } \\
\text { cally. }\end{array}$ \\
\hline & $\begin{array}{l}\text { Specific Didactics for } \\
\text { Gastronomy }\end{array}$ & $\begin{array}{l}\text { Model specialty didactics through the why, what for and } \\
\text { how reflection on each of the class stages. }\end{array}$ \\
\hline Teaching Im- & Neuroeducation & To provide helping tools to develop teaching technical \\
\hline
\end{tabular}




\begin{tabular}{|l|l|l|}
\hline provement Plan & $\begin{array}{l}\text { General Didactics } \\
\text { Learning Evaluation }\end{array}$ & competences. \\
\hline \multirow{2}{*}{$\begin{array}{l}\text { Complementary } \\
\text { Courses }\end{array}$} & Service -Learning & $\begin{array}{l}\text { To bring academics closer to this teaching strategy with } \\
\text { respect to its methodology for its implementation. }\end{array}$ \\
\cline { 2 - 3 } & $\begin{array}{l}\text { Intellectual property and } \\
\text { Author Rights }\end{array}$ & $\begin{array}{l}\text { To guide teachers in the correct and responsible use of } \\
\text { information sources. }\end{array}$ \\
\hline
\end{tabular}

In order to specialize the teacher training at INACAP, the institution generated a cooperation strategy with the International Centre of Engineering Education (CIEI) at the University of Talca (Chile), under the pedagogical support of the Technische Universität Dresden (Germany), Faculty of Education. The aim of the project was to strengthen specifically Engineering teaching and technical and professional education, through online training and certification of teachers in different fields of Engineering Pedagogy, but the first step was to recognize and analyse the training needs of the academic staff of INACAP at the Talca campus.

\section{A Needs Analysis on Engineering Pedagogy at INACAP}

\subsection{Methodology}

The survey was designed using a mixed model of qualitative and quantitative methods. The aim is to use two different survey methods to confirm, supplement, or validate the research results [10]. The main goal of the research design was to integrate the opinions of the participants (academic staff) with the valuation of engineering-pedagogical needs that are most required for the teaching-learning process of engineers.

Based on their previous experience at engineering pedagogy research projects in Germany and Chile, the authors developed categories and indicators [11, 12], which later were used in the data collection instrument about the teaching needs of the engineering schools of INACAP at the Talca campus. In general, the instrument and indicators seek to obtain information about: (i) the characteristics of lecturers (gender, subject matter, fields of teaching experience, previously teacher training, etc.), (ii) the needs related to engineering didactic fundamentals, (iii) the requirements for the structuring of teaching-learning forms in a university context, (iv) needs for the development of teaching-learning strategies in engineering, (v) demands of the setting of objectives and contents of engineering programs, and (vi) the identification of strengths and weaknesses [11,12, 13,14]. 
Table 3. Dimensions and categories of the research instrument.

\begin{tabular}{|c|c|}
\hline Dimension & $\begin{array}{c}\text { Categories/ Items * } \\
\text { (simplified version for this publication) }\end{array}$ \\
\hline $\begin{array}{l}\text { General aspects from engineering } \\
\text { didactics }\end{array}$ & $\begin{array}{l}\text {-Theoretical and practical knowledge about didactics for the teaching } \\
\text { and learning in engineering. } \\
\text {-Structuring of teaching - learning processes for the scientific education } \\
\text { of engineers. } \\
\text {-Knowledge for determining teaching contents in engineering for the } \\
\text { personal, technical and social activities of engineers. } \\
\text {-Didactic principles for the teaching - learning process in engineering. } \\
\text {-Fundamentals for determining the specifically contents within de engi- } \\
\text { neering field. } \\
\text {-Knowledge about special teaching-learning strategies at university level } \\
\text { (Case study, observations of learners, among others). } \\
\text {-Knowledge and skills for the preparation, execution and feedback of } \\
\text { teaching. } \\
\text {-Organization of the teaching - learning processes for the trainings of } \\
\text { engineers. } \\
\text {-Knowledge about the design of teaching-learning processes for labora- } \\
\text { tory work. } \\
\text {-Analysis of specific topics about the concrete activities of engineers and } \\
\text { specific knowledge from the engineering sciences. }\end{array}$ \\
\hline $\begin{array}{l}\text { General aspects from educational } \\
\text { science }\end{array}$ & $\begin{array}{l}\text {-Organization and planning of the teaching - learning processes. } \\
\text {-Design of communication process. } \\
\text {-Knowledge about the fields of action of the didactic media and ICT. } \\
\text {-Knowledge about the design of didactic media for the teaching - learn- } \\
\text { ing process. } \\
\text {-Knowledge about the procedures for the recollection and measurement } \\
\text { of learning outcomes. } \\
\text {-Evaluation and assessment of learning outcomes. }\end{array}$ \\
\hline
\end{tabular}

The survey instrument was an opinion poll type instrument with open and closed questions, oriented to identify the perceptions about the teaching needs in different pedagogical aspects related to the engineering subjects at INACAP. The main goal of the instrument was to identify the training needs and interests in the pedagogical and didactical aspects and requirements of major importance for the formation of engineers. Table 3 shows the dimensions and categories of the instrument.

\subsection{Population, available sample and procedure}

The sample of the study was composed by 28 academics of four Engineering Schools of INACAP at the Talca campus: Industrial Engineering, Mechanical Engineering, Electrical Engineering and Information and Computer Engineering. The questionnaire was applied online, ensuring the absolute anonymity of the participants. The first part collected general information of the participants (gender, subject matter, fields and years of teaching experience, previous teacher training, etc.). The second and third parts correspond to the information collection of the closed questions. The statistical analysis applied was exploratory-descriptive to raise problems. The fourth part consists of open questions. These questions were analysed through textual analysis by codifying the discourse of each participant, based on the item generating con- 
ceptual categories. The instrument considers ethical aspects according to the Chilean social sciences research criteria.

\subsection{Characterization of the sample}

The selected sample of academics that participated in the survey and responded the questionnaire completely was approximately $20 \%$ of the total number of academics of the Engineering School of INACAP at the Talca campus (156 academics). Table 4 presents the characterization of the INACAP sample. In total, 28 academics were gathered with $32 \%$ women (9) and $68 \%$ men (19). Of the total respondents, $89 \%$ were engineers by profession (25), the rest had similar professions that help to complement the total training of the future engineers. Regarding the age ranges of the respondents, $68 \%$ (19) of the survey participants are between 30-39 years old, 18\% (5) are between $40-49$ years old and $14 \%$ (4) are over 50 years old.

Table 4. Characterization of the sample.

\begin{tabular}{|l|c|}
\hline \multicolumn{1}{|c|}{ Categories } & Sample \\
\hline Number of respondents & 28 \\
\hline Age & \\
\hline Between 30 and 39 years old & 19 \\
\hline Between 40 and 49 years old & 5 \\
\hline Between 50 and 59 years old & 4 \\
\hline More than 60 years old & 0 \\
\hline Gender & \\
\hline Female & 9 \\
\hline Male & 19 \\
\hline Engineering fields & 4 \\
\hline Mechanical engineering & 5 \\
Computer sciences/ engineering & 10 \\
Industrial engineering & 9 \\
\hline Electrical engineering & \\
\hline Teaching experience (in years) & 21 \\
\hline Between 0 and 5 years & 6 \\
\hline Between 6 and 10 years & 1 \\
\hline More than 10 years & \\
\hline Previous experience at teacher trainings & 18 \\
\hline Yes & 10 \\
\hline No & \\
\hline
\end{tabular}

Concerning the years of teaching experience, $75 \%$ have between $0-5$ years (21) and $21 \%$ have between 6-10 years (6). Of the total number of participants, approximately $64 \%$ (18) have already participated in university teaching training programs. Related to the participant's distribution by engineering school at INACAP, most of the participants work in industrial engineering (36\%) and electrical engineering (32\%). Fewer participants work in the fields of computer sciences (18\%) and in mechanical engineering $(14 \%)$. 


\subsection{Results of INACAP's survey}

Closed questions: The results about the perception of the academic staff (respondents) regarding the needs for different skills and pedagogical tools for university teaching in engineering careers are presented in this section. It was asked "How necessary do you consider the following aspects of engineering pedagogy concerning your teaching experience?" For this section, 28 aspects were considered based on the indicators of Table 3 .

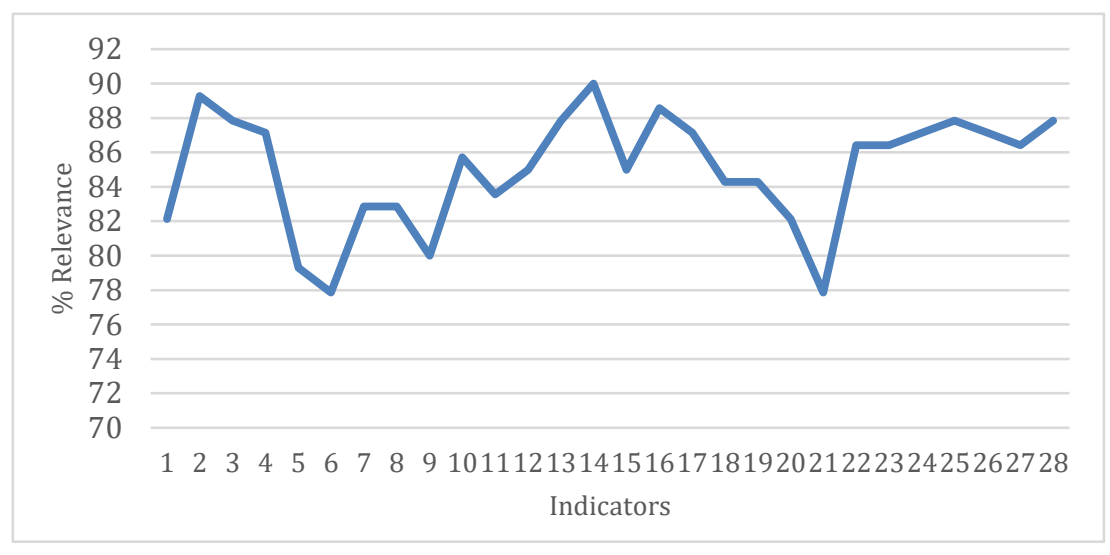

Fig. 1. Relevance of the different aspects of needs in Engineering Pedagogy.

The relevance of the different aspects about needs in Engineering Pedagogy is presented in Figure 1. In general, all aspects were considered relevant with more than $78 \%$ of the preferences. The most relevant aspects are related to the dimension "General aspects from educational science" (see Table 3) with more than $88 \%$ of the preferences, specifically indicators such as: "Evaluation and assessment of achieved learning" and "Knowledge about design for effective measurement of achieved learning" are high valuated. Then with more than $84 \%$ of the preferences are different indicators from dimension "General aspects from engineering didactics" and also "General aspects from educational science" (see Table 3): "Use and development of new didactic means in the training of engineers", "Structuring of teaching-learning processes in the scientific training of engineers" and "Use of didactic resources and information and communication technologies (ICTs)" for instance: "Knowledge about procedures of collection and measurement of achieved learning"," Knowledge about collection procedures and measurement of achieved learning" and "Support elements such as projector, blackboard, materials, etc". The aspects with the lowest relevance (under 80\%) were: "Curriculum development for academic training at the university level", "Realization of communicative processes for teaching at university level" and "Resolution of specific problems on the design of instruments for the assessment of teaching-learning processes". 


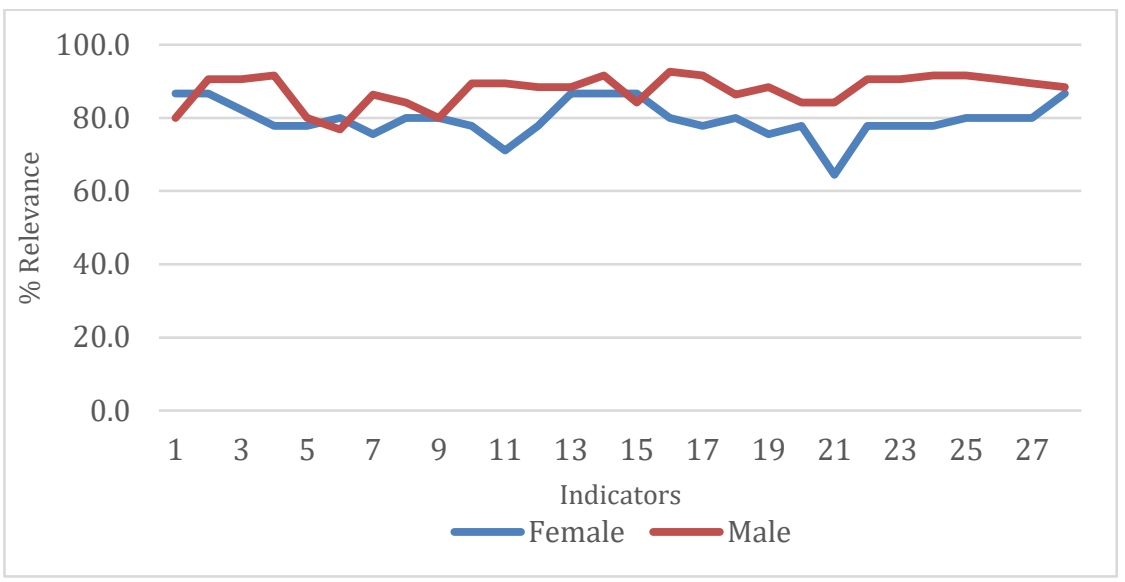

Fig. 2. Relevance of the different aspects of needs in Engineering Pedagogy by gender.

By grouping the participants by gender (Figure 2), the female participants (9) have more than $80 \%$ of preferences on aspects related to "Evaluation" and "Teaching and learning structuring", for instance: "Evaluation and assessment of achieved learning" and "Planning and materialization of evaluation and evaluative processes" but also "Structuring of teaching-learning processes in the scientific training of engineers". The worst evaluated aspects by the female gender correspond to the "Dialogic and monological communicative processes for teaching" (70\%) and "Planning of activities for individual study" (65\%).

In the case of men (19), the most of the aspects were considered with a relevance over $85 \%$. The aspect "Use of didactic resources and information and communication technologies (ICTs)", and "Development of didactics media in EE", "Planning of activities for individual study" "Evaluation and assessment of learning achieved" and "Knowledge about the design for effective measurement of learning achieved" have preferences over $90 \%$. For males the worst evaluated aspects correspond to "Recognition and resolution of conflicts within the classroom" and "Psychological foundations for teaching and learning" with $80 \%$ and $78 \%$ respectively. 


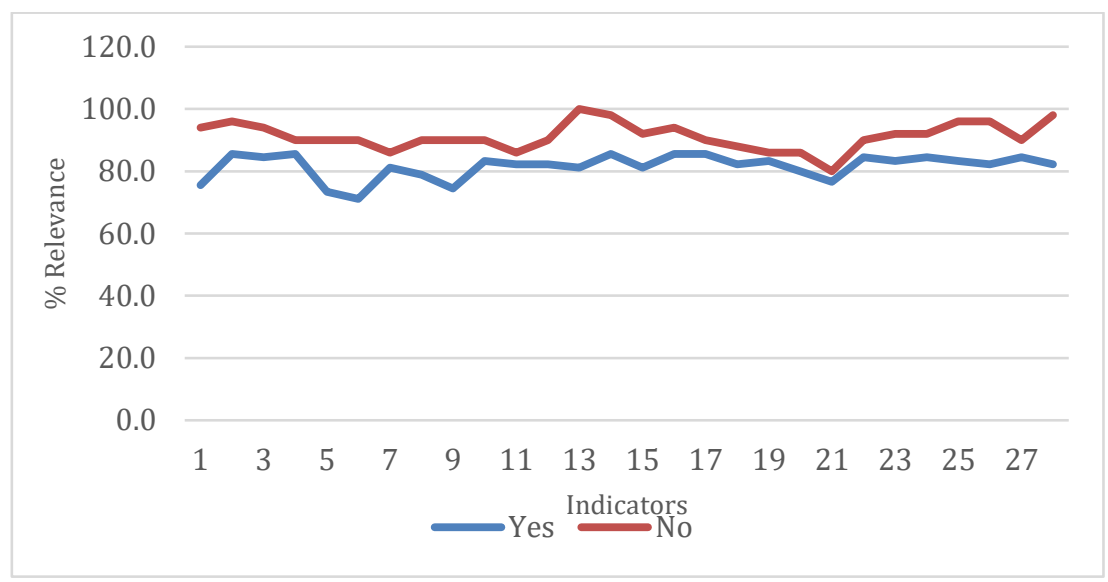

Fig. 3. Relevance of the different aspects of needs in Engineering Pedagogy by previous teacher training.

Another important aspect is the perceptions of the relevance of the different indicators /questions for the participants concerning their previous (or not) experiences in teacher training programs. Figure 3 shows the differences between the relevance of the indicators for the participants. For the participants without previous participation at teacher training programs, all "needs in Engineering Pedagogy" are more valued (average of $8 \%$ of difference).

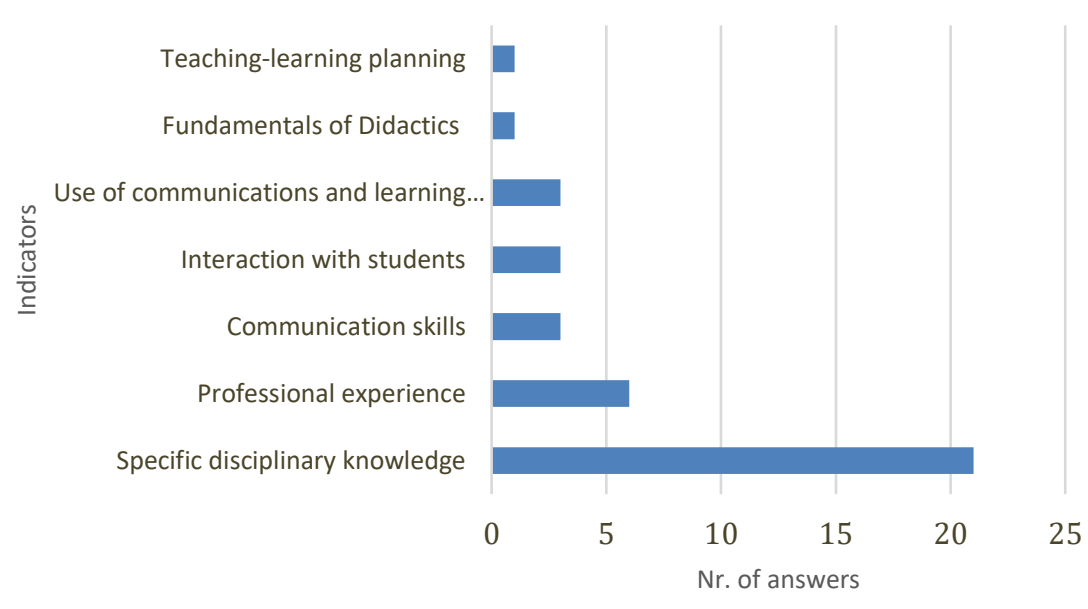

Fig. 4. Professional strengths in Engineering Pedagogy

Open questions: This part of the survey presents the answers of the participants regarding four aspects: (1) strengths in engineering pedagogy; (2) aspects to be improved in the teaching task; (3) interest and availability to train in the engineering 
pedagogy area; and (4) conditions necessary to attend a training in engineering pedagogy.

The answers for the aspects 1 and 2 are presented in Figures 4 and 5 respectively.

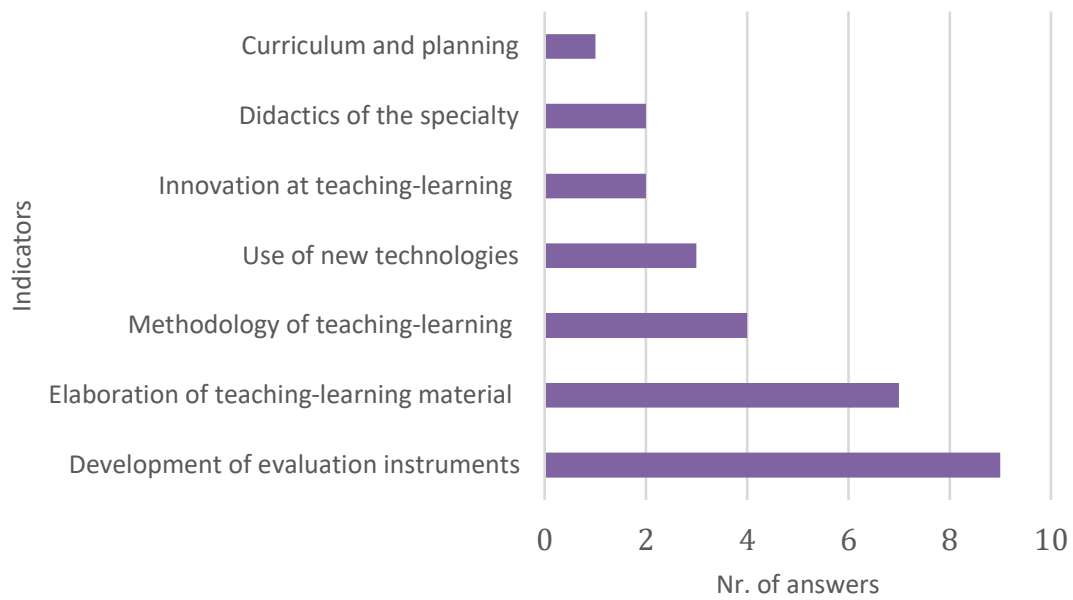

Fig. 5. Professional weaknesses in Engineering Pedagogy (to be improve)

Regarding the interest to take part in a teacher training course, all the participants are interested in a training course of this type, but $68 \%$ of the participants (19) will participate in a "more oriented" or "specific oriented" training course for engineering educators and in online modality $(75 \% ; 21$ participants).

The design of a specific teacher training course should consider the applicability of the acquired knowledge, it must be dictated by specialists with expertise in teaching and learning on engineering, and it should promote the design of evaluation strategies in engineering education, with innovative methodologies and tools, focused on students of the 21 st century, among others.

\section{Conclusion}

This research project was aimed to show the training needs in engineering pedagogy and education of the academic staff in the engineering schools of a large Chilean educational institution, such as INACAP, that works at university and vocational school level (post-secondary). Based on the knowledge and experiences in the field of Engineering Pedagogy of the Technical University of Dresden and the University of Talca, several aspects that contextualize the education and training programs for university teachers in engineering were presented: most of them are designed from a generic vision of university education and not specialized in Engineering Pedagogy.

From the survey results presented, it can be concluded that exists a high level of interest and motivation to participate in a training course in engineering pedagogy, 
which has been especially oriented and designed to meet the requirements of the academic staff of engineering schools.

The academic staff of INACAP has recognized the need for continuous learning in several areas of engineering education (not only in strategies and teaching methods) in the context of the demands of the students and the society of the 21 st century, but specifically from the perspective of the engineering education context. Therefore, considering these requirements, the academic staff of the International Centre for Engineering Education (CIEI) of the University of Talca, designed an online teacher training course specifically based on the needs detected. In future work, the authors of the present publication hope to present the results of the implementation and evaluation of that training course. It is also expected that these results will serve as a basis for promoting academic training in Engineering Education in Chilean universities and vocational schools.

\section{References}

[1] Köpeczi-Bócz, T. (2020). Learning Portfolio and Proactive Learning in Higher Education Pedagogy. International Journal of Engineering Pedagogy, 10 (5): 34 - 48. https://doi.org/ $\underline{10.3991 / \text { ijep.v10i5.13793 }}$

[2] Hrmo, R., Miština, J., Krištofiaková, L. (2016). Improving the Quality of Technical and Vocational Education in Slovakia for European Labour Market Needs. International Journal of Engineering Pedagogy, 06 (2) : 14-22. https://doi.org/10.3991/ijep.v6i2.5369

[3] Wuryaningsih, W., Susilastuti, D.H., Darwin, M., Pierewan, A.C, (2019). Effects of WebBased Learning and F2F Learning on Teachers Achievement in Teacher Training Program in Indonesia. International Journal of Emerging Technologies in Learning, 14 (21): 123 147. https://doi.org/10.3991/ijet.v14i21.10736

[4] Clara Ventura, A. (2016). ¿Enseño como aprendí?: el rol del estilo de aprendizaje en la enseñanza del profesorado universitario. Aula abierta, 44: 91-98. https://doi.org/10.1016 j.aula.2016.05.001.

[5] Sobrino García, J. (2019). Evaluación sistemática de un programa de formación docente para profesores de la Universidad de Castilla-La Mancha. Universidad de Castilla-La Mancha, España. https://doi.org/10.18239/ins.131.2019

[6] Pérez Rodríguez, N. (2019). Programas de Formación Docente en Educación Superior en el contexto español. Investigación en la Escuela, 97: 1-17. https://doi.org/10.12795/ie. 2019.i97.01

[7] Pontificia Universidad Católica de Chile (2019). Diplomado en Docencia Universitaria. Facultad de Educación PUC. Santiago, Chile. https://doi.org/10.14349/rlp.2019.v51.n3.4

[8] Universidad de Chile (2019). Diplomado en Innovación y Docencia Universitaria. Departamento de pregrado Universidad de Chile. Santiago, Chile. https://doi.org/10.19137/ qs0929

[9] Universidad de Talca. (2019). Programa de formación pedagógica basada en el modelo de competencias". Documento interno Vicerrectoría de Pregrado. Talca, Chile. https://doi.org/ $\underline{10.29035 / \text { ucmaule. } 58.59}$ 
[10] Creswell, John W (2003). Research design: Qualitative, quantitative, and mixed method approaches. Sage Publications University of Nebraska, Lincoln Nebraska.

[11] Gormaz-Lobos D., Galarce-Miranda C., Hortsch H., Kersten S. (2020). Engineering Pedagogy in Chilean Context: Some Results from the PEDING-Project. In: Auer M., Hortsch H., Sethakul P. (Eds.) The Impact of the 4th Industrial Revolution on Engineering Education. ICL 2019. Advances in Intelligent Systems and Computing, 1135: 101-114. https://doi.org/10.1007/978-3-030-40271-6_11

[12] Gormaz-Lobos D., Galarce-Miranda C., Hortsch H., Kersten S. (2020). The NeedsOriented Approach of the Dresden School of Engineering Pedagogy and Education. In: Auer M., Hortsch H., Sethakul P. (Eds.) The Impact of the 4th Industrial Revolution on Engineering Education. ICL 2019. Advances in Intelligent Systems and Computing, 1134: 589-600. https://doi.org/10.1007/978-3-030-40274-7 56

[13] Schreurs,J,, Dumbraveanu, R. (2014). A Shift from Teacher Centred to Learner Centered Approach. International Journal of Engineering Pedagogy, 4 (3): 36- 41. https://doi.org/10.3991/ijep. v4i3.3395

[14] Rüütmann, T., Kipper, H. (2014). Design, Implementation and Analysis of LearnerCentered Guided In-Service Programme for Technical Teacher Education, International Journal of Engineering Pedagogy, 4: (2): 4-9. https://doi.org/10.3991/ijep.v4i2.3363

\section{Authors}

Dr. phil. Diego Gormaz-Lobos. Dr. Gormaz-Lobos formerly studied Education (B.A) at the Pontificia Universidad Católica de Chile. He completed a Master Degree and a Ph.D. program in Education at the Technische Universität Dresden (Germany) specializing in university and technical education. Between 2014 and 2020, Dr. Gormaz-Lobos worked as a Research Assistant at the Technische Universität Dresden, Faculty of Education. Diego is currently part of the academic staff of the Faculty of Engineering at the University of Talca (Chile) and he is executive director of the International Center of Engineering Education (CIEI).

Dr. phil. () Claudia Galarce- Miranda M.A. Dr. (C) Galarce- Miranda studied Education (B.A) at the Pontificia Universidad Católica de Chile. She studied a Master program in Education with a specialization in Education Research at the Technische Universität Dresden (Germany). Between 2012 and 2014 she worked as a Research Assistant in a project dedicated to the development of digital learning platforms at the Technische Universität Dresden. Claudia is currently part of the academic staff of the International Centre of Engineering Education at the University of Talca (Chile), Faculty of Engineering. She is finishing a Ph.D. program at the Freie Universität Berlin, Germany. Her doctoral thesis focuses on didactics of mathematics.

Prof. Dr. paed. habil. Hanno Hortsch. Prof. Dr. Hortsch is an electro-mechanic who obtained a Ph.D. in Sciences, Methodology and a Ph.D. in Vocational Pedagogics, Didactice and Methodics. Presently, Dr. Hortsch serves as the President of the IGIP and as the Director of the IGIP Training Institute Dresden. He also serves as the Chair for Didactics of Vocational and Professional Learning and Teaching Education at the Technische Universität Dresden. Prof. Dr. Hortsch was selected as the 2017 
recipient of the IFEES Duncan Fraser Global Award for Excellence in Engineering Education. He has decades of experience in engineering education and has played a pivotal role in pedagogical development in Germany and abroad.

Carolina Vargas-Almonacid M.A Carolina Vargas-Almonacid studied a Master program in Education with a specialization in Competence Development and Research at the University of Talca (Chile). Since 2010, she has been involved in different activities for the teacher's training and competence development of students. She is currently part of the academic staff of INACAP as academic director of the campus Talca.

Article submitted 2021-01-21. Resubmitted 2021-02-26. Final acceptance 2021-02-26. Final version published as submitted by the authors. 